\title{
Sir Edward Hyde and the Problem of Counsel in Mid-Seventeenth-Century Royalist Thought*
}

\section{JACQUELINE ROSE}

The Civil Wars of the mid seventeenth century brought to the fore a number of pressing issues surrounding the politics of counsel. In the English theatre of that conflict, counsel provided a useful tool by which parliament first criticised the policies of the 1630s Personal Rule, then levered itself into position as the dominant element within the mixed constitution, and ultimately claimed sovereignty. The crucial phase of parliamentary manoeuvring, from the autumn of 1641 to the summer of 1642 , was a major contributor to the formation of the royalist party which Charles I had lacked a year before. Overplaying their hand, the English parliamentary opposition to Charles demanded unprecedented restraints on royal authority backed up by orchestrated mob violence in London. Parliament's insistence that the king ought to take their advice rather than that of his privy council is a salient reminder that the role of counsel remained central to political argument on the eve of Civil War. Nevertheless, the period after 1642 has seen minimal historiographical attention to counsel. The assumption, explicitly stated by John Guy and James Hart, is that the 1640s and 1650s were the point where counsel vanished, temporarily or permanently, from political life. For Guy, in the 1650 s the rhetoric of counsel became 'redundant'; for Hart, the regicide wiped away 
'notions of accountability, of advice and consent, and of counsel'. ${ }^{1}$ This chapter questions these assumptions, demonstrating that the language of counsel remained a vital part of English royalist thought after 1642 .

Royalists, as recent studies have shown, were far from a united or uniform group. David Smith emphasised the 'constitutional royalists', critics of Charles I's prerogative rule who swung in mid-1641 to the king as the best guarantor of the established law. ${ }^{2}$ Their manifesto was the Answer to the XIX Propositions of June 1642, which famously positioned Charles as the capstone of a mixed and balanced constitution consisting of monarchy, aristocracy and democracy - king, Lords and Commons as the three estates of the realm. Nonetheless, as other scholars have emphasised, constitutional royalists did not enjoy a monopoly of the king's side, and the Answer was condemned as erroneously giving away too much (demoting the king to a mere estate and omitting the bishops entirely). Barbara Donegan has described the king's party as a 'rainbow coalition', while David Scott rejects a juridical and constitutional taxonomy in favour of a division between those willing to ally with French, Irish or Scottish Catholics and Presbyterians and those who wanted to protect

* My thanks are due to Paul Seaward, Roger Mason, Colin Kidd and an external referee for commenting on a draft of this article.

${ }^{1}$ J. S. Hart, jr, 'Rhetoric and Reality: Images of Parliament as Great Council', in M. Braddick and D. L. Smith (eds), The Experience of Revolution in Stuart Britain and Ireland (Cambridge, Cambridge University Press, 2011), p. 94; J. Guy, 'The Rhetoric of Counsel in Early Modern England', in D. Hoak (ed.), Tudor Political Culture (Cambridge, Cambridge University Press, 1995), p. 310.

${ }^{2}$ D. L. Smith, Constitutional Royalism and the Search for Settlement (Cambridge, Cambridge University Press, 1994). cf. P. Seaward, 'Constitutional and Unconstitutional Royalism', Historical Journal, 40 (1997), 227-39. 
the Church of England even at the cost of military defeat. ${ }^{3}$ While Scott is correct to see a constantly shifting pattern of quarrels and changing alliances, he underestimates the way in which these could provoke and reflect constitutional or ideological differences of opinion about royal powers.

This chapter demonstrates the continuing centrality of counsel to one leading royalist, Sir Edward Hyde, later earl of Clarendon, an important figure from the 1640s to the 1660s, but one who is hard to place unambiguously as a 'constitutional' or 'unconstitutional' royalist. It first outlines how Hyde refuted parliament's claims to conciliar dominance through arguments partly shared with, and partly distinct from, those in the famous Answer to the XIX Propositions. This evidences how counsel could be used either to support or to depress pretensions to power. It then shows how the factious character of Civil War and Interregnum royalism provoked Hyde and his allies into a series of claims about the importance of the privy council (or at least of privy councillors) to securing the monarchy, before exploring the apparent paradox of their insistence on respect for the council while practising counsel outside it. Here Hyde's work demonstrates the complex relationship between institutional councils and informal counsel, and how important the oath of a councillor was to seventeenth-century advisers' sense of what they were undertaking in counselling rulers. The final two sections turn to consider the subtle ways in which Hyde attributed royalist failures to both bad counsel and bad kingship and how he navigated giving unwelcome advice to monarchs. In what circumstances could counsel be withheld and how could criticisms of royal policy be made? How did Hyde, who saw counsel as founded on friendship, work with councillors he despised?

\footnotetext{
${ }^{3}$ B. Donegan, 'Varieties of Royalism', and D. Scott, 'Counsel and Cabal in the King's Party, 1642-1646', in J. McElligott and D. L. Smith (eds), Royalists and Royalism during the English Civil Wars (Cambridge, Cambridge University Press, 2007).
} 
Thus as both a practitioner and theorist of counsel, Hyde provides a useful case study of how Stuart statesmen could conceive of the relationship between council and counsel, whether they blamed monarchs for bad decisions or fell back on scapegoating evil counsellors and the way in which they located good rule in a moral framework in which counsel helped maintain social as well as political relationships. These questions will be explored through the Declarations which Hyde penned on the king's behalf during the 1640s, his correspondence in the 1640s and 1650s, his History of the Rebellion and Life, and his other, less well known, writings of the early 1670s. These are not transparent texts - the History in particular was begun in 1646, resumed in Hyde's second exile after his impeachment in 1667 and imperfectly revised with chunks of the Life spliced into it. ${ }^{4}$ As Brian Wormald showed in 1951, Hyde retrospectively rewrote his career as a firm supporter of episcopacy, when he had been much more lukewarm about this originally. ${ }^{5}$ Nevertheless there is sufficient consistency across all these works to draw conclusions about counsel as an elusive, yet crucial, part of Hyde's conceptual apparatus. ${ }^{6}$ They bear witness to both counsel's continuing importance and its ambiguities.

\footnotetext{
${ }^{4}$ P. Seaward, 'Introduction', to his edition of Edward Hyde, earl of Clarendon, The History of the Rebellion (Oxford, Oxford University Press, 2009).

${ }^{5}$ B. H. G. Wormald, Clarendon: Politics, History, and Religion, 1640-1660 (Cambridge,
} Cambridge University Press, 1951). While Wormald rightly emphasised the significance of counsel in Hyde's thought up to 1642, he did not explore its continuing role in the rest of Hyde's career.

${ }^{6}$ B. Worden, 'Clarendon: History, Religion, Politics', in his God's Instruments (Oxford, Oxford University Press, 2012), esp. pp. 377, 396-400, rightly points out the importance of counsel to Clarendon, and some crucial elements of his attitude towards it. The present chapter brings these elements to the forefront of discussion. 
In moving from condemning specific individuals as tools of arbitrary rule to generally constraining the king's power to appoint privy councillors and great officers of state, English MPs were following in the footsteps of their Scottish Covenanting brethren. Charles's visit to Scotland in August to October 1641 had involved a heated dispute over parliamentary consent to appointments of great officers of state. ${ }^{7}$ When he returned to England, he faced the same argument, which became entangled with the practical politics of two linked flashpoints: control of the militia and the response to Catholic rebellion in Ireland.

On 5 November 1641 the leader of the parliamentary opposition to Charles, John Pym, offered an 'Additional Instruction' which refused aid to suppress the Irish Rebellion 'unless the King would remove his evil counsellors and take such counsellors as might be approved by Parliament'. Significantly, it was Hyde who (according to the diarist D'Ewes) 'stood up and first opposed it'. Changes to conciliar practices were more important than attacks on the Church in Hyde's move from being a critic to a supporter of the king. ${ }^{8}$ Pym

${ }^{7}$ The Nicholas Papers: The Correspondence of Edward Nicholas, Secretary of State, ed. G. F. Warner, 4 vols (Westminster, Nichols and Sons, 1886-1920; henceforth Nicholas), I, 3852.

${ }^{8}$ J. P. Kenyon, The Stuart Constitution (Cambridge, Cambridge University Press, 1966), p. 227; Wormald, Clarendon, pp. 20-22. A motion about great officers of state of 28 October was in 'so extreme a strain as Mr Hyde did upon a sudden confute most of it'. For discussion of parliament's claims described in this section see M. Mendle, 'The Great Council of Parliament and the First Ordinances: The Constitutional Theory of the Civil War', Journal of British Studies, 31 (1992), 133-62. 
had to withdraw his suggestion of parliamentary approval of councillors and, a month later, the Grand Remonstrance begged instead for the appointment of those 'Parliament may have cause to confide in'. While Charles promised to appoint able advisers, he swiftly asserted his 'undoubted right' to summon whom he pleased. ${ }^{9}$ In the months following Charles's departure from London after his failure to arrest his leading opponents in January 1642, the fissures between future royalists and Parliamentarians began to widen.

Counsel loomed large in this process of polarisation. Significantly, both sides praised it, but simultaneously evidenced very different understandings of it. On 19 February 1642 parliament demanded Charles admit only those advisers they recommended, and exclude the queen entirely from policy making, appointments and counsels. ${ }^{10}$ While this direct attack on the king's wife fell away in the following months, the demand that the king reject 'private' counsel in favour of parliament and their appointees echoed throughout the declarations and counter-declarations of 1642. The first of the Nineteen Propositions, parliament's main manifesto, required parliamentary approval of existing and future privy councillors and officers of state, the second that public affairs be debated in parliament, not by 'private ... unknown or unsworn councillors' and that decisions appropriate to the privy council only be deemed valid if taken by 'the advice and consent of the major part of your council, attested by their hands'. ${ }^{11}$

The declarations which Hyde penned on Charles's behalf had the king posturing (as in the Answer to the XIX Propositions) as a defender of law against a parliament undermining it

\footnotetext{
${ }^{9}$ Kenyon, Stuart Constitution, pp. 230, 239; Edward Hyde, earl of Clarendon, The History of the Rebellion and Civil Wars in England, ed. W. D. Macray, 6 vols (Oxford, Clarendon, 1888, repr. 1958; henceforth History, cited by volume and page number), I, 436-7.

${ }^{10}$ History, I, 526-7; Wormald, Clarendon, pp. 58, 110-13.

${ }^{11}$ Kenyon, Stuart Constitution, pp. 244-5; History, I, 579, 585, 589.
} 
by an arbitrary rule which would introduce parity and confusion. Evil counsel was denounced as a mere figleaf for an attack on the king. ${ }^{12}$ But while Hyde's declarations stated that the king was a necessary part of parliament, unlike the Answer they refrained from talking about the estates. ${ }^{13}$ Most importantly, they twisted counsel into a claim to depress parliament's power. In April 1642 Hyde ventriloquised for the king an acknowledgement of parliament as the great council whose advice would be considered, but subordinated its counsel to 'Our Understanding ... any Right we had ... Our own Interest and freedom'. Parliament offered its conciliar 'Opinion' to the king, but he was 'free to discent [sic] (till Our Reason be convinced for the general good)'. ${ }^{14}$ In April and May parliament's declarations grew bolder. First insisting that the king ought to assist his own understanding by the wisdom of parliament (the eyes in the body politic), the Houses eventually crossly asserted that 'the votes of the Lords and Commons in Parliament, being the Great Council of the kingdom, are the reason of the King and of the kingdom'. Eventually they declared their exercise of 'the King's supreme and royal pleasure ... after a more eminent and obligatory

${ }^{12}$ History, II, 52-3; His Majesties Declaration to both Houses of Parliament ... in Answer to that Presented to Him at Newmarket the 9 of March 1641 (London, 1642, Wing C2266), p. 3; His Majesties Answer to the Declaration of both Houses of Parliament concerning the Commission of Array of the First of July 1642 (Cambridge, 1642, Wing C2116), p. 5. For Clarendon's authorship of these see G. Roebuck, Clarendon and Cultural Continuity (New York, Garland, 1981). Wormald sees a change in the tone of Hyde's works from 26 March, but asserts an underlying continuity in his stance: Clarendon, pp. 83-4.

${ }^{13}$ His Majesties Declaration to All his Loving Subjects of the 12 of August 1642 (York, 1642, Wing C2249), p. 89; see Wormald, Clarendon, pp. 11-12.

${ }^{14}$ The Humble Petition of the Lords and Commons ... Presented to his Majesty, 18 April (York, 1642, Wing E1577), pp. 18-20. 
manner than it can be by [his] personal act'. ${ }^{15}$ Throughout the 1640s, the language of evil counsel continued to be a motivating tool in recruitment to the Parliamentarian side, cited by soldiers, preachers and in raising revenue. If rhetorical justification of behaviour, it could also motivate action: it was invoked in 1643 by the Earl of Stamford in his refusal to surrender Exeter to the king until Charles left the counsel of 'old serpents' and 'caterpillars' and directed himself 'by the light of your Majesty's best council, the Parliament' ${ }^{16}$

While the Houses' claims grew, the royalist refutation remained static: every assertion of parliament's special conciliar status was met with a polite acknowledgement of their role as a council, but one offering mere counsel. They were Charles's 'counsellors, not commanders, (for, however they frequently confounded them, the offices were several,) and counsellors not in all things, but in some things, de quibusdam arduis, etc'. ${ }^{17}$ While Hyde did not endorse the idea of three equally empowered and balanced estates described in the latter half of the Answer, there was some shared ground. Like Hyde, the first half of the Answer urged parliament to trust the king to choose the correct counsellors, promised to remove any who acted illegally and twice offered that they swear an oath to maintain the whole law. The suggestion that parliament approve councillors and that the king be obliged to have them sign off his orders provoked an angry claim that this would be the 'worst kinde of minority', 'at once to depose both Our Self and Our Posteritie'. Disdainfully, Charles's mouthpieces insisted that he be able to take advice 'from any person known or unknown, sworn or unsworn', as he, like any subject, had the right 'of discoursing with whom We please, of what

\footnotetext{
${ }^{15}$ History, II, 104, 131 (emphasis mine); Kenyon, Stuart Constitution, p. 249.

${ }^{16}$ History, II, 179, 314, 321; State Papers Collected by Edward Earl of Clarendon, 3 vols (Oxford, 1767-86; henceforth Clar. SP), II, 151.

${ }^{17}$ History, II, 153-4.
} 
We please', in or out of the council, and to treat their suggestions 'as Advices, not as Commands'. ${ }^{18}$

This drew on a growing seventeenth-century tendency to deploy the language of counsel to diminish rather than claim power. In the sixteenth century the claim that a person was a counsellor acted as a marker of status and boosted their prestige. In the early Stuart era, it was used by monarchs to denigrate their opponents. Thus where Elizabeth I had refuted unwelcome parliamentary advice with the claim that she would hear other counsel, under Charles I parliament's conciliar status was acknowledged but treated as inferior. Elizabeth deflected the Commons with the assertion that she would answer their plea for her to marry 'upon further advise' or that she had conferred with the 'well learnede and ... askede theyre opynyns' on the succession. ${ }^{19}$ She might tell MPs that they were not counsellors on a particular matter, but she was less inclined to disparage counsel per se than Charles, who began to stress the distinction between advice-givers and commanders in his speeches to parliament:

His Majesty doth not forget that the Parliament is his Council, and therefore ought to have the liberty of a council; but His Majesty understands the difference between council and controlling, and between liberty and the abuse of liberty.

Charles's supporters likewise denigrated counsel: at the Ship Money trial, Sir Robert Berkeley admitted that parliament was 'commune concilium regis et regni', but snidely added

${ }^{18}$ His Majesties Answer to the XIX Propositions (London, 1642), esp. sigs. A2v-Br, B3r of Wing C2123A.

${ }^{19}$ T. E. Hartley, Proceedings in the Parliaments of Elizabeth I, 3 vols (London and Leicester, Leicester University Press, 1992-5), I, 95, 147. 
'yet give me leave to say that it is but a concilium'. ${ }^{20}$ Hyde's works do not go so far, but they reflect this new tendency to use conciliar status as a way of demeaning his opponents. He admitted that a good parliament could provide useful advice. Parliamentary counsel was legitimate when invited by the king. However, such assemblies risked becoming fora for populist politicking. So he endorsed limited and specific parliamentary privileges, including freedom of speech, but saw this as a problematic privilege because it both underpinned conciliar status and generated the excessive freedom of popular councils. ${ }^{21} \mathrm{He}$ was willing to present the king as open to parliamentary advice at the Restoration. But he was also keen to exercise caution: the king should consider what a free parliament would think fit to ask, but not promise to settle the kingdom as parliament should advise. ${ }^{22}$

Seventeenth-century writers all agreed counsel was an important element of good rule. However, they quarrelled over whether it should be institutionalised in councils and, if so, which ones (parliament or privy council), and how far the king was obliged to heed them. An initial survey of Hyde's works suggests that he thought the privy council ought to be the main source of counsel. Throughout his career he complained of whispers outside the privy council which both Charles I and Charles II were too inclined to heed. These undermined the

${ }^{20}$ Constitutional Documents of the Puritan Revolution, ed. S. R. Gardiner, 3rd edn (Oxford, Clarendon, 1906), pp. 4-5; Kenyon, Stuart Constitution, p. 114.

${ }^{21}$ Edward Hyde, earl of Clarendon, A Brief View and Survey of the Dangerous and Pernicious Errors to Church and State in Mr Hobbes's Book, entitled Leviathan (Oxford, 1676), pp. 57-8; History, III, 293-4, I, 532-4, 7-8.

${ }^{22}$ History, VI, 204; Clar. SP, III, 289. 
authority of a crucial institution and thus of the king. In book three of his History, penned on Jersey in 1646 , he offered a paean of praise to the privy council as the basis for 'the reputation, if not the government, of the State'. Hyde suggested that an ideal council would contain a variety of opinions within bounds. Councillors must uphold the king's 'essential' 'dignity ... freedom ... [and] jurisdiction', although they might debate the best means to do so. Ostensibly commenting on the 'bridge' appointments of 1641 , by which Charles I brought some of his critics onto the council to neutralise them, but probably with the divisions which had dogged the royalist cause between the mainly civilian Oxford privy council and the mainly military king's council of war in mind, Hyde insisted that monarchs could not be too careful in choosing their councillors. On this 'much of their safety, more of their honour and reputation (which is the life itself of princes) both at home and abroad, necessarily depends'. The council should be kept small, to avoid delegating business to subcommittees which made ostensible members feel excluded. This was partly a comment on the failures of the Personal Rule, partly one of the problems of royalist councils in the 1640s. Princes should also avoid choosing 'mean' men. ${ }^{23}$ 'Mean' was one of the keywords of Hyde's political vocabulary. Occasionally carrying social connotations, it more frequently bore a moral implication. The moral and political failings of critics of the council are symbolised by one of Hyde's royalist enemies, George, Baron Goring, who slides seamlessly from 'his usual license of drinking, and then inveighing against the Prince's council' to 'inveighing likewise in an unpardonable dialect against the person of the King'. ${ }^{24}$

${ }^{23}$ History, I, 259-61; III, 223-6 makes the reference to 1640 s councils clear. See also Worden, 'Clarendon', p. 396.

${ }^{24}$ History, IV, 63. After the Restoration, Hyde would complain of 'mean' Presbyterians entering the privy council: The Life of Edward Earl of Clarendon, 2 vols (Oxford, Oxford University Press, 1857; henceforth, Life), I, 276. On the royalist councils see I. Roy, 'The 
Hyde's justification for the importance of the privy council did not rest on an exalted view of monarchy. A widely respected council was vital since a king was 'not thought a great monarch when he follows the reins of his own reason and appetite, but when, for the informing his reason and guiding his actions, he uses the service, industry, and faculties of the wisest men'. ${ }^{25}$ This fairly traditional statement of the importance of supplementing an individual man's imperfect knowledge with broader wisdom, with an added gloss of the importance for the king's reputation of doing this, was presented as an explanation of why the bridge appointments had failed. ${ }^{26}$ Charles had brought onto the council a group of men who believed they owed their places to their importance in parliament, and thus refused to advise the king as to when he should reject parliament's demands. But even more to blame were the other councillors who 'most supinely and stupidly' accepted this, failing in their 'duty' to advise the king on his relations with parliament and to dissuade him from giving up his prerogative rights. ${ }^{27}$ As will be seen, for Hyde counsel was a moral obligation, not just a political duty.

The need to boost the prestige of the institutional council was often reiterated by Hyde, his friend Edward Nicholas (secretary of state) and their correspondent and fellow member of the Oxford privy council Christopher Hatton, Baron Hatton. Writing to Nicholas in January 1655, Hatton complained that the influence of the queen's favourite Jermyn at the exiled court meant 'wee are looking at single governing [i.e. a minister-favourite] and not at

Royalist Council of War, 1642-6', Bulletin of the Institute of Historical Research, 35 (1962), 150-68; Scott, 'Counsel and Cabal'.

${ }^{25}$ History, I, 261.

${ }^{26}$ Although this is retrospective: Hyde had originally supported these appointments and could even be seen as one of them: Wormald, Clarendon, pp. 5-7.

${ }^{27}$ History, I, 262; Worden, 'Clarendon', p. 380. 
union of councells and the honour of a councell bord, without which monarchy will never buoy up again'. In March he repeated that only 'a well ordred vnited councell' would solve royalist fractiousness. 'Councell, Councell vnited and resolutly pursued, must doe the deed, or nothing.' 28

Hyde and Nicholas found a model for a successful and prestigious privy council in Elizabethan history. Nicholas emphasised how Charles I

lost all by despising of councils and by undervaluing of counsellors, so Queen Elizabeth kept up her honour and esteem by the value she set on councils and on her counsellors.

This monarch

would never endure to hear any person speak slighting words of any of her council, saying that they were her outworks and that whosoever should go about to slight them would in the next place assault her. ${ }^{29}$

Where this view of Elizabeth's virtuous regard for her council came from is hard to pin down: perhaps from her proclamations and speeches, perhaps from works commemorating her. Royalists were clearly reading Elizabeth's first historian, William Camden: Hyde had done so in the 1620s and in October 1655 the Clerk of the Council Joseph Jane apologised to Nicholas that he could not find a copy of Camden in The Hague, but promised to send one via a mutual contact in Cologne. ${ }^{30}$ But Camden's history does not depict Elizabeth as

\footnotetext{
${ }^{28}$ Nicholas, II, 155-6, 230-1.

${ }^{29}$ Nicholas, I, 305, 311-12.

${ }^{30}$ Nicholas, III, 83. On Elizabeth's view of counsel, see Susan Doran's chapter in this volume.
} 
influenced by a wise council, an image which seemed to begin in the 1650 s. $^{31}$ Yet a decade earlier, Nicholas had asked for extracts from the council records of its 'most signal acts of power ... in the best of times; as in the times of H.7. H.8. Q. Eliz and beginning of K. James' ${ }^{32}$

\section{III}

Despite this frequent praise for the institution of the privy council, its place in the practice of Hyde's counsel to the king seems remarkably limited. Partly this was a matter of practical necessity - as its members were scattered by warfare and exile, they could not meet as a body to advise the king. But Hyde's passing mentions of where and how he counselled monarchs place these encounters in informal settings and not formal meetings. He met Charles I on the backstairs when the king was half dressed, in the privy gallery with the door locked, in his bedchamber and often walking in the garden, this last being 'a fit opportunity ... when [Charles I] was always most willing to be entertained'. ${ }^{33}$ It is possible that these episodes were retrospectively re-imagined and cited to demonstrate Hyde's intimacy with the king. Yet even if the depictions are inaccurate, their inclusion shows that Hyde thought it acceptable to depict himself and the king violating the need to hear the privy council rather than whispers on the back stairs.

${ }^{31}$ J. Watkins, Representing Elizabeth in Stuart England (Cambridge, Cambridge University Press, 2002), pp. 102-3; J. Watkins, ““Old Bess in the Ruff”: Remembering Elizabeth I, 16251660', English Literary Renaissance, 30 (2000), 95-116. Paulina Kewes suggests to me that this might have derived from plays.

${ }^{32}$ Clar. SP, II, 382-3.

${ }^{33}$ Life, I, 99, 101, 111, 123-5, 143-4, 154 (qu.). 
Throughout his career Hyde would seek and give counsel outside the institutional council. He urged Charles II to circulate the draft proclamation in response to the regicide beyond the council to test support for it. ${ }^{34}$ After 1660, he encouraged the restored king to make major decisions outside formal council meetings, which merely ratified them. He praised the 'secret committee ... which, under the notion of foreign affairs, were appointed by the king to consult all his affairs before they came to a public debate'. ${ }^{35}$ Clarendon refers to meetings of this secret committee in his house or chamber in ways which suggest it was used to iron out disagreements. Use it, he urged the king, 'that we may be of one mind'; 'if you please to walk one turn in the gallery after Council, you will be able the better to prepare' for the next formal council meeting. ${ }^{36}$

How might we reconcile this apparent conflict between an insistence on respect for the privy council and willing use of secret individual counsel? One answer would be not to expect coherence. Hyde's comments are scattered throughout the thousands of pages of his History, Life, essays and correspondence rather than systematised in a single formal treatise. Another would be to say he was willing to do whatever it took to get his advice to the king. But a third possibility is that Hyde and Nicholas did not conceive of the privy council as a series of formal meetings, but as a group of people who had sworn a particular oath to the king. When we examine their works closely, we see a division between the king's sworn councillors, heard in whatever setting, and his unsworn ones. ${ }^{37}$ Attending to the oath helps us

${ }^{34}$ History, V, 42.

${ }^{35}$ Life, I, 315.

${ }^{36}$ Clar. SP, III, supplement, xlvii-xlix.

${ }^{37}$ Thus the committee for foreign affairs might in practice have removed debate from the privy council, but this was perhaps acceptable if it was constituted entirely of privy councillors. This contrasts with E. I. Carlyle, 'Clarendon and the Privy Council', English 
move away from the institutional and administrative history of the privy council beloved by nineteenth- and twentieth-century historians, and re-orientate ourselves to early modern understandings of this body.

Passing references to the oath suggest how important it was to these royalists. Sometimes its moral weight remained implicit, as when Hatton linked the disastrous attempt by Henrietta Maria to convert the king's younger brother, the Duke of Gloucester, to Catholicism in 1654 on private counsel overriding the king's 'sworn Privy Council'. ${ }^{38}$ When the earl of Bristol converted to Catholicism in 1659 Hyde seemed particularly pained at this defection by a 'sworn' councillor. When especially moved, he would mention the oath. He invoked it to justify his own behaviour in condemning his daughter's unauthorised marriage to the Duke of York, pressing the king to send her to the Tower 'upon all my oaths which I have taken to you to give you faithful counsels'. So important was the oath, he wrote elsewhere, that the king could not dispense with it. ${ }^{39}$

Occasionally the importance of the oath was made more explicit. Hatton bemoaned how those advising the king outside the privy council were under less moral restraint than those 'true Councellors' who had sworn it, who had thereby bound themselves to care for the public good. In early 1650, when Hatton made this remark, care for the public good translated into protecting the Church of England by not entering into the alliance with Presbyterian Scotland advocated by those surrounding Henrietta Maria at her base in the Louvre. The advisers he complains about are those of 'the Louvre Presbyter and Scot designe'. Hatton's following comment that the king should not share secrets and counsel Historical Review, 27 (1912), 251-73, which emphasises the institutional council, not committees; perhaps because Carlyle based his account on Hyde's Life.

${ }^{38}$ Nicholas, II, 129-30.

${ }^{39}$ Life, I, 425, 325; History, I, 258. 
with any except 'a well chosen competent number of wise and discreete, but above all religious and faithfull, sworne councellors' is less an insistence that proper counsel comes from an institutional setting than on the importance of recognising the moral obligations counsel involves. ${ }^{40}$ If for Hatton the oath's utility lay in the obligation to serve the public good, for Hyde it appears to have been the requirement to keep the king's affairs secret - in the context of his constant moaning that the Louvre group around the queen chatted about Charles's affairs in the most indiscreet way. Leaking council secrets was, he noted, 'directly contrary to their oath' ${ }^{41}$ Hyde agreed with Nicholas that new councillors should be formally sworn in, although admitted that his opponents' lack of principles made oaths of limited use as a form of moral gatekeeping. If such men had no moral sense, Hyde pointed out, then they might take an oath they did not truly believe in. Thus the oath was not a reliable way of excluding undesirable advisers. But it was a way of reasserting a morally grounded government which would exercise due prudence, but not succumb to the reason of statist tendency to endorse all expedients in an effort to win back power.

Although Charles II took on his father's councillors in 1649, it appears - strikingly that most remained unsworn until April 1653, perhaps not coincidentally, one of the periodic points of Interregnum regime change. ${ }^{42}$ This poses an unexpected problem: what oath did these people actually swear? Contrary to common historical parlance, there was no single oath of a privy councillor. Over the previous eighty years, a number of different oaths had been sworn. Comparing them shows both the changing understanding of what counsel was for, and the pressure of immediate circumstances. Two versions exist from 1558. One, drafted by William Cecil, swore the taker to counsel 'as maye best ... tend to the safety' of

\footnotetext{
${ }^{40}$ Nicholas, I, 161-2.

${ }^{41}$ Clar. SP, III, 8.

${ }^{42}$ Clar. SP, III, 162.
} 
queen and commonweal, reflecting the security concern at the forefront of the fledgling Elizabethan regime's mind. The second, like Walter Mildmay's of 1567, by contrast promised to advise 'all things that may be to the Queenes hono' ${ }^{\mathrm{r}}, \&$ behalfe, \& to the good of her realmes, Lor ${ }^{\mathrm{ps}}, \&$ subjects'. Yet even this did not remain in place for long. The oath taken by Shrewsbury in 1571 (which provided the base text for those of the following decades) did not contain this clause, although it maintained the promise of impartiality, allegiance and secrecy. The last extant before Hyde was writing, that in the privy council register of October 1640, insisted on true and faithful service to the king, protecting his 'person, honour, Crowne, or dignity Royall' and jurisdiction. The counsellor swore to keep matters of counsel secret, and to declare his opinion 'according to your heart, and Conscience' ('conscience' being a new addition of 1613). In general the 1640 oath was tilted much more strongly towards upholding royal authority than the early Elizabethan ones, matching the trend towards using counsel to uphold rather than restrain royal authority. Hatton's emphasis on a sworn councillor's requirement to care for the public good is striking, for although this was a fundamental feature of early Elizabethan oaths, it at no point appears in the oath of $1640 . .^{43}$

These royalists' regard for the oath was partly a result of their emphasis on a moral rather than constitutional framework for good government. Virtuous rule was not created by

${ }^{43}$ TNA, SP 12/1, fo. 2v, 12/1/62, 12/83/33 (Shrewsbury’s); Bodleian Library, Oxford, Tanner MS 88, fo. 4 (Mildmay's); Acts of the Privy Council of England, ed. J. R. Dasent, 45 vols (London, Eyre and Spottiswoode for HMSO, 1890-1964), XXXIII, 4-5 (1613); Privy Council Registers, 12 vols (facsimile edn, London, HMSO, 1967-8), XII, 7. Shrewsbury's oath echoes that of 1426 for which see my introductory essay to this volume, p. 00 . I hope to write further on these developments elsewhere. 
a set of institutional limitations on monarchs but by encouraging good behaviour. ${ }^{44}$ There may also have been another stimulus. The Civil Wars had exposed the tensions inherent in apparently platitudinous promises to serve the king and his crown, as the Parliamentarians initially built their case on defending the monarchy against the person of Charles Stuart. Furthermore, while previous historians have acknowledged parliament's claims of 1641 to 1642 to approve or appoint privy councillors, they have neglected the parallel calls for parliament to determine the oath advisers swore. While the Grand Remonstrance was less radical than the Additional Instruction in dropping calls for approval of councillors, it introduced the requirement 'that all Councillors of State may be sworn to observe those laws which concern the subject in his liberty'. The Nineteen Propositions stated that councillors should swear to 'the due execution of their places, in such form as shall be agreed upon by both Houses' and that they and the judges should swear to 'the maintaining of the Petition of Right and of certain statutes made by Parliament'. ${ }^{45}$

Royalists insisted that the king ought to be able to choose his councillors. Could they have accepted parliament imposing an oath on them? In the dark post-regicidal days of September 1649, Hyde was seemingly willing to countenance an act 'for the swearing all Privy Councellors to the observacion of the Lawe'. ${ }^{46}$ Striking though this looks, it cohered with his sense of the best monarchy being a self-restraining one, which would observe established laws. It also combined a statutory basis with a framework for conciliar good behaviour independent of the whims of parliament - councillors would swear to uphold 'the Lawe' generally, not specific statutes. Yet for all Hyde's insistence on the importance of the oath as a way of encouraging good counsel, he may have recognised that this could not

\footnotetext{
${ }^{44}$ Seaward, 'Royalism', p. 230; Worden, 'Clarendon', p. 396.

${ }^{45}$ Kenyon, Stuart Constitution, pp. 240, 244, 246.

${ }^{46}$ Nicholas, I, 142; cf. His Majesties Answer, sigs. A3r, [B4]r.
} 
totally fence in a pair of kings too much inclined to take the wrong advice. Did the problems of the king's party stem from bad counsel, or from a failure of kingship?

\section{IV}

Advocates of counsel often appear to be unimaginatively falling back on banal pleas for good rule, based on an ingenuous belief that kings would be able to identify and be willing to take good advice. Hyde's works demonstrates that those reflecting on counsel were far from naïve, for he criticised both the givers and the recipients of bad counsel. When analysing royalist losses in the climacteric year 1645, he rebuked the laziness and negligence of his own side, particularly their 'irresolution and unsteadiness ... ill humour and faction', a party who erred 'sometimes in deliberating too long without resolving, and as often resolving without any deliberation, and ... not executing vigorously what was well deliberated and resolved'. Directly confronting the question of whether this was the king's fault, he admitted that Charles I could not be entirely exonerated, but insisted that the king's greatest failing was 'to depart often from his own reason, to follow the opinions of more unskilful men'. ${ }^{47}$ This passage was penned in 1671 , when criticism of the royal martyr could only be couched in veiled terms, and the king was largely excused by a comment on how hard it was to find good ministers. Yet this was a significant change from Hyde's original draft of late June 1646, which sought to vindicate not the king, but Hyde and other members of the Prince of Wales's council for blame for the failure of the royalist campaign in the West Country. ${ }^{48}$ The imperfectly edited text which remains thus wobbles uneasily between bemoaning slanders of the prince's council and rebuking monarchs for listening to these. This was not purely a

\footnotetext{
${ }^{47}$ History, IV, 2-4. On the themes of this section see also Worden, 'Clarendon', pp. 398-9.

${ }^{48}$ History, IV, 8n.
} 
function of a retrospective account: Hyde's correspondence emits the same mixed messages as his History and Life.

Occasionally Hyde optimistically argued that Charles I and his son would be able rulers if they used their own judgement rather than relying on the bad counsel of others. Indeed, throughout the 1650s Hyde was much more positive than Nicholas or Hatton about Charles II's abilities and resistance to evil counsel from his mother's associates. He was 'an excellent man' and would fulfil all expectations 'if he hath good men about him' he wrote on 3 May 1652. Three weeks later he admitted that 'appetite and affection' did sometimes triumph, 'which we must all labour by good counsel to prevent and divert', but suggested that 'when we have done our duty we must make the best of what we cannot help, and must always remember that Kings are of the same mould and composition as other men'. ${ }^{49}$ This looked like a complacent reiteration of one of the commonplaces of theoretical treatises on counsel - kings are flawed mortals who need advice to overcome their passions.

But on other occasions Hyde directly blamed monarchs for failing to rule well.

Charles I heeded the wrong counsel and changed fixed and carefully debated resolutions on a whim. Fatally, he 'frequently considered more the person who spoke, as he was in his grace or his prejudice, than the counsel itself that was given'. This cohered with Hyde's reading of the historian of the fifteenth-century French civil wars, Philippe de Commynes, who commented acidly on monarchs' poor judgment of character. Rereading Commynes in 1646 Hyde noted Commynes's comment on how princes 'abhor being compelled to anythinge ther owne inclinations do not leade them, though never so profitable and advantageous' ${ }^{50}$ Hyde

${ }^{49}$ Clar. SP, III, 65, 71, 4, 171, 204.

${ }^{50}$ History, III, 344; P. Seaward, 'Clarendon, Tacitism, and the Civil Wars of Europe', Huntington Library Quarterly, 68 (2005), 289-311, at 292; Seaward, intro. to Hyde, History, p. Xv. 
also noted how both Charles I and his son were far too willing to countenance those who slandered the privy council. The Prince of Wales was contented to sit in council to learn his royal trade, but when he met his old nurse he failed to discourage her criticising the council. Again, some of the harsher criticisms could not be publicly circulated; Hyde felt it acceptable to say the prince had little experience, but struck out of the manuscript his comment that he had not 'spent his time so well towards the improvement of his mind and understanding as might have been expected from his years and fortune' ${ }^{51}$ Charles II's laziness would continue to be something 'which vexes me exceedingly' - indeed, one of the treason charges levied against Hyde by his enemies in the exiled court in 1654 was reportedly his comment that Charles was too lazy. ${ }^{52}$ Hyde was especially pained by Charles's willingness to make promises which he reneged on, generating not just deleterious political instability, but also a series of distressing moral dilemmas. ${ }^{53}$

These criticisms were established before the Restoration and they did not go away afterwards. While Clarendon clung to the argument that the king acting on the basis of his own reason was the solution to the problem of bad counsel, he seemed to lack confidence in his monarch's ability to do so. Ironically, while Clarendon urged the king to act independently, his own influence was often criticised. Such complaints were dramatised after his impeachment by the disaffected Robert Howard. Howard's play The Great Favourite, or the Duke of Lerma offers a thinly-disguised account of an overweening minister whose daughter becomes the object of the king's affections, parodying the union of Clarendon's daughter with the duke of York. Lerma/Clarendon 'seems / To make you [the monarch] practice power unlimited; / Just then you have the least, obeying his'. Ironically given

\footnotetext{
${ }^{51}$ History, III, 444, IV, 21-2.

${ }^{52}$ Clar. SP, III, 170, 173, 154; Nicholas, II, 40.

${ }^{53}$ Clar. SP, III, 13, 59; Life, I, 568.
} 
Hyde's emphasis on the privy council, Howard depicts it as 'wither'd' 'strangers' to the business of a king who has lost all majesty to his favourite. 'If you look after him that shou'd be King / You may perhaps find him in Lerma's pocket. ${ }^{54}$ Yet Howard also criticises the king for having 'Resign'd my Reason to / My Love'. Charles' sexual inclinations are as problematic as his minister's machinations. ${ }^{55}$

Clarendon insisted that the extent of his power derived from a lazy ruler devolving business to him. ${ }^{56}$ While his account is self-exculpatory his language is nonetheless significant. The word licence - another one of his favourite terms - is deployed to complain both about the king's pleasure-mongering and about his excessive accessibility. The king's licence creates a court with 'all doors open to all persons' such as the Spanish ambassador, who undermines his carefully planned Portuguese marital alliance. It leaves him open to the Presbyterians who nearly got him to delay the enforcement of the 1662 Act of Uniformity. ${ }^{57}$ And it renders him vulnerable to 'the witty men for the evening conversation' who first joked with the king and then censured his trusted counsellors (Clarendon) and their 'very mature' resolutions. ${ }^{58}$ His choice of terms is significant, for licence carried with it the moral baggage

${ }^{54}$ Sir Robert Howard, The Great Favourite, or the Duke of Lerma, in Restoration Drama: An Anthology, ed. D. Womersley (Oxford, Blackwell, 2000), III.ii.57-8, III.i.90-1, II.ii.211-12. On the relationship between Howard and Clarendon see P. H. Hardacre, 'Clarendon, Sir Robert Howard, and Chancery Office-Holding at the Restoration', Huntington Library Quarterly, 38 (1975), 207-14.

${ }^{55}$ Howard, Lerma, III.ii.19-20. See also Pepys' entry for 20 Feb. 1668. ${ }^{56}$ Life, I, 346-7.

${ }^{57}$ Life, I, 305, 428-30, 309, 564-5. See B. Weiser, Charles II and the Politics of Access (Woodbridge, Boydell, 2003).

${ }^{58}$ Life, I, 589-90, 354-5. 
of passion overriding reason, and thus of weak tyranny (i.e. a monarch good natured in themselves, but who is unable to resist evil advice). Charles II is a king who cannot treat counsel seriously and does not recognise good counsel when it is offered. He did not take the advice of his father's Eikon Basilike but he did read 'too concernedly' a book about Henri IV's love affairs. ${ }^{59}$ The premier Irish royalist Ormond shared this view, writing in exasperation in 1658 of the king's 'immoderate delight in empty effeminate and vulgar conversations' - no wonder, since he was trying to recover the king's correspondence to Lucy Walter, mother of his child, which she threatened to make public in late 1657 if he failed to pay her a promised annuity; Charles then attempted to have his bastard kidnapped. ${ }^{60}$ Ormond nevertheless felt such an explosion of criticism should not be said 'but to you or him' since if it came 'from any (unless a very few) but from me, or from me at any other time were too bold a lamentation' ${ }^{61}$ Recognising that a monarch contributed to bad counsel was one thing, solving this problem quite another.

Having used counsel to analyse Hyde's view of kingship, we may now turn to the underlying question of what he thought counsel was and what duties it involved. Counsel was vital to

${ }^{59}$ Nicholas, I, 190; Life, I, 588.

${ }^{60}$ T. Harris, 'James Scott, duke of Monmouth and first duke of Buccleuch', ODNB [accessed 1 April 2014]. This would later be used to assert that the king had married her and that the child, the future duke of Monmouth, was the legitimate heir.

${ }^{61}$ Clar. SP, III, 387. 
Hyde's moral universe as a crucial element of sociability, that is, of friendship. ${ }^{62}$ Friendship echoes throughout Hyde's writings as the means by which men maintain moral rectitude. Strikingly, almost every political actor who gets into trouble does so, according to Hyde, because they lack a friend who can give wise counsel. Hyde here reflected the early modern understanding of friendship, steeped in a classical tradition which saw advice as the first obligation of amicitia. ${ }^{63}$ Hyde praised his own friends for saving him from his youthful follies $;{ }^{64}$ he thus believed that the king's confidants were similarly tasked with saving the ruler from moral and thus political decline. The mutual trust ('confidence') and friendship of Hyde's circle with each other and with, he sometimes asserts, their king, should provide a stable reciprocally supportive clique in which frank and honest advice can be exchanged and appreciated. $^{65}$

At one level, therefore, counsel is a particular form of sociability. Clarendon's essays of 1670 linked counsel to the 'second Education' of conversation, noting the damage done to good natures by evil conversation. This explains why Hyde, Hatton and Nicholas fretted about who dined with Charles II and York. ${ }^{66}$ An interest in the king's companions was not just a product of the exiled royalist rumour-mill, but also an important marker of who might be influencing his character. Since sociability and friendship fostered the trust which made

${ }^{62}$ See Worden, 'Clarendon'; although cf. G. Smith, The Cavaliers in Exile, 1640-1660 (Houndmills, Palgrave Macmillan, 2003), p. 201, on Hyde's exile as 'studded with broken friendships'.

${ }^{63}$ Life, I, 461-2; Edward Hyde, earl of Clarendon, 'Of Friendship', in A Collection of Several Tracts (London, 1727), p. 131.

${ }^{64}$ Life, I, 8, 27.

${ }^{65}$ History, V, 223; Life, I, 270-3, 309, 492.

${ }^{66}$ Clarendon, 'Of Counsel', in Collection; Nicholas, II, 343, IV, 13; Life, I, 360. 
free speech acceptable to its recipients, the ability to speak candidly signalled counsel was working well. One of the major contributing factors to the war, according to Hyde, was royalists' unwillingness to speak freely and honestly to the king. ${ }^{67}$ Conversely, when conciliar relationships broke down - as in the argument in 1646 over whether to send the Prince of Wales to France or to keep him in Jersey - a 'sudden reservedness and strangeness' resulted. ${ }^{68}$ Lack of friendship, reproof and freedom of conversation and counsel were linked results, symptoms and causes of the Civil War. ${ }^{69}$

Under what circumstances was Hyde prepared to speak freely to the king? A distinction must be drawn between criticism of appointments and of policy. Despite his dislike of many of his fellow exiles in the 1650s, Hyde maintained his position that the king alone should choose his privy councillors. Wary of the ways in which parliament had first criticised and then demanded control over conciliar appointments, he told Nicholas that to object to the king's choice was tantamount to rebellion. Even to speak openly in council against the king's preferred appointees would be unacceptable. Although he might dislike a fellow councillor, 'where it cannot be altered I do assist him' since to deliberately thwart him would be to act 'no less a Rebel than Cromwell'. ${ }^{70}$ Even more than this, such men must have full knowledge of the king's affairs: secrecy was necessary outside the council, but within it 'we must consult with those whom he chooses'. Yet Hyde distinguished conciliar collegiality from 'the entire communication as is necessary to friendship'. ${ }^{71}$ Friendship requires 'entire Confidence and Communication', 'faithful Counsel' and 'the Authority of Reprehension', but

\footnotetext{
${ }^{67}$ Clarendon, 'Of Counsel'; Worden, 'Clarendon', p. 380.

${ }^{68}$ Life, I, 204; Clar. SP, III, 21.

${ }^{69}$ Life, I, 307; His Majesties Declaration ... 12 of August, p. 82.

${ }^{70}$ Clar. SP, III, 40, 87-8, 118.

${ }^{71}$ Clar. SP, III, 106, 172-3.
} 
counsel can exist without friendship (or was part of an inferior type of friendship among less good men). ${ }^{72}$ Whether Hyde believed that counsel to a king replicated the ordinary structures of proper friendship or saw this as a unique type of interaction is hard to pin down. He wavers over this in his essay 'Of Friendship': according to classical principles that friends must be social equals, it is impossible for kings. Yet he then urges kings to have a friend if possible. ${ }^{73}$ Maybe Hyde thought that true friendship with a king was possible, but never achieved this with either monarch with whom he worked, in contrast to the real friendships he forged with Nicholas and Ormond. Lack of friendship meant that both kings were unwilling to accept Hyde's unpalatable advice.

While a king's choice of unsavoury fellow-councillors had to be accepted, there were certain policies which Hyde felt unable to endorse. Often these involved the 'expedients' of a French or Scottish alliance, or the passage of the Prince of Wales to France. This rejection of Catholic or Presbyterian alliances was not a retrospective autobiographical fiction but a stance which can be found in Hyde's 1640s correspondence. Indeed, the rejection of 'this wilderness of prudential motives and expedients' made Hyde protest in November 1648 that he was no fit counsellor. His insistence that he could serve the Queen 'with all integrity and fidelity, reserving only so much liberty of judgment as an honest man cannot part with' raises the question of the extent to which Hyde would have accepted royal decisions with which he disagreed. ${ }^{74}$ A counsellor had a duty to give unwelcome advice. They ought to submit to the king's decisions but did not, he claimed, have actively to obey or endorse those they disliked. Thus he submitted to the decision that Prince Charles be sent from Jersey to Paris for his safety in 1646, but never endorsed it, and flatly refused to accompany him.

\footnotetext{
${ }^{72}$ Clarendon, 'Of Counsel', and 'Of Friendship'; Worden, 'Clarendon', p. 382.

${ }^{73}$ Clarendon, 'Of Friendship', pp. 134-5.

${ }^{74}$ Clar. SP, II, 459, 458.
} 
In his professions of willingness to withdraw from counsels he found distasteful, immediately followed by pleas to get himself back into the action, Hyde was the heir of William Cecil: counsel was their political oxygen, the air they breathed. Like Cecil, Hyde was willing to strain the boundaries of criticism of royal policy, to find policies incompatible with his conscience and to yearn for retirement. But, just like Cecil, he did not wish to be left out. In his letter of November 1648, immediately after his plea that he might be an unfit counsellor, he urged the Queen to call Charles I's councillors (including himself) to attend the Prince in France. ${ }^{75}$ After a flow of letters begging for renewed favour, he wrote to Nicholas in March 1650 - the point at which Charles was engaged in detailed negotiations with Scottish Covenanters - stating that however much he might wish his friend to enjoy an easy retirement it was vital to serve the king if called to his council. Perhaps the result was explosive. It was at this time that Sir John Berkeley, who had been subjected to a series of letters from Hyde urging him not to abandon moral foundations for expedients (read: the Church of England for Covenanters), wrote to Hyde complaining of his 'overweening' invectives. $^{76}$

Unwelcome advice had to be carefully offered. Royalists engaged in a variety of strategies for so doing, citing a duty to serve their king, their conscience or their birth as justifications for criticism. ${ }^{77}$ Henrietta Maria could invoke her love for the king, perhaps in a unique way, to offer unwelcome advice. ${ }^{78}$ Warning the Duke of York against rumours that

${ }^{75}$ Clar. SP, II, 352-4, 459, 418; S. Alford, 'The Political Creed of William Cecil', in J. F. McDiarmid (ed.), The Monarchical Republic of Early Modern England (Aldershot, Ashgate, 2007), pp. 85-6.

${ }^{76}$ Clar. SP, II, 523-4, 530.

${ }^{77}$ Clar. SP, III, 669-70, II, 56-7, 261, 268-9. All could cite conscience.

${ }^{78}$ Clar. SP, II, 303. 
he was planning to convert to Catholicism, George Morley, future bishop of Worcester and Winchester, enacted all the unspoken rules of counsel. Morley apologised for it, he sought permission to give it, he gave it in a discreet conversation, he adopted a posture of humility and begged pardon again at the end:

I desired him to give me leave to speak something to him, which I conceived myself obliged unto in conscience towards God and in duty to his Highness and the whole Royal Family. He told me he would hear me very willingly, and then withdrawing to a window he bid me speak freely ... Sir, said I, I humbly and earnestly beseech you to consider, whether there can possibly be any thing more prejudicial to the King's, and next to the King's, to your Highness's own interests and pretensions in England than that it should be generally believed or probably suspected, that the King or your Highness are Papists, or at least well affected to, or favourers of those that are of that religion ... I concluded with begging his Highness's pardon for the liberty I had taken in speaking to him. His answer was, that he did not only pardon but thank me, and should do so as often as I told him of any thing that so much concerned him. ${ }^{79}$

Clarendon likewise proceeded cautiously when required to give unwelcome counsel, also using a parrhesiastic apology when advising Charles II on how to be reconciled with his estranged wife. Never in his correspondence or in his later recollections did he invoke friendship as a justification for advice at the moment of providing counsel to kings, although he cited it often in discussions with his own clique. ${ }^{80}$

\footnotetext{
${ }^{79}$ Clar. SP, III, 458-9.

${ }^{80}$ Life, I, 492, 600. On parrhesia see D. Colclough, Freedom of Speech in Early Stuart England (Cambridge, Cambridge University Press, 2005).
} 
In his Life Clarendon naturally depicted the king as willing to be admonished by him. Nevertheless the repeated sense is of counsel rejected. ${ }^{81}$ Perhaps the only solace for the rejected counsellor was a clear conscience. As Morley noted, all that he expected from his harangue of York was 'but the comfort I shall find in having discharged mine own conscience'. ${ }^{82}$ But this does not mean that the rejected counsellor is the failed counsellor. This raises an important question about how we judge the 'success' or 'failure' of political counsel. At the highest level success obviously involves one's advice being followed. But, even if it is ignored, lack of punishment for giving it is a form of victory: signifying mutual agreement between monarch and subject of the legitimacy of that person giving advice on a particular topic at a certain time. This type of second order success was available to Clarendon until 1667, when his impeachment shattered his sense of being accepted as a royal counsellor and servant.

\section{VI}

Forged in the circumstances of civil war and exile, Clarendon's writings on counsel manifest the concerns of a particular group of royalists about the risks of eroding the moral foundations of kingship. Their fears were less of their Parliamentarian and republican opponents than of their royalist companions-in-arms who sought restoration at almost any cost. Getting Charles I and Charles II to hear the correct advice was of immediate political importance, in terms of preventing a policy of Catholic or Presbyterian military alliance. But counsel also played a crucial role in ensuring the monarch would restrain themselves from violating the ancient laws of the realm, and in rooting rule in a morally-grounded sense of

\footnotetext{
${ }^{81}$ Life, I, 355-6, 590, 598.

${ }^{82}$ Clar. SP, III, 459.
} 
good kingship. Well-counselled kings would avoid the excesses of the Personal Rule and thereby prevent Parliamentarian radicalism as well. To royalists of this bent, respect for the institution of the privy council was an important marker of royal willingness to follow conciliar proprieties, but the duties of a good counsellor were embodied in an oath, not an institution. For Clarendon, king and counsellors were above all bound to a set of moral fundamentals which would provide their guiding lights in navigating political realities. To counsel was a constant exercise in casuistry, successful management of which would bring the monarchy safe ashore in England again.

Clarendon's writings demonstrate that the idea of counsel was far from 'redundant' after 1642. It retained a leading place in concepts of good rule. Though Clarendon looks like a firm advocate of a constitutional monarchy paired with a strong institutional council, he is better understood as an advocate of counsel - a diffuse element of sociability and friendship as well as a quotidian political activity. Clarendon's writings offer no naïve, utopian or banal faith in generic good counsel. Rather, they evidence deep recognition of the difficulties involved in making advice work. Hyde was concerned with some fundamental problems of advice-giving: how its moral requirements could work in reality, how to cooperate with undesirable fellow-councillors, how to engage with recalcitrant kings and how to keep counsel secret. These were not new questions, but the events of the 1640s, 1650s and 1660s brought them to the forefront of royalists' minds. Counsel properly understood would deflate parliament's pretensions to power-sharing and would restrict any risk of a Catholic or Presbyterian backed restoration.

Hyde never stopped thinking about counsel. In his 'Essay on an Active and a Contemplative Life', penned in his second exile of the early 1670s, he praised a life of service to other men through giving 'gentle and civil cautions and animadversions', a nexus of mutual improvement which fulfils the virtue of charity because "no charity is comparable 
to the charity of instruction and of seasonable reprehension'. ${ }^{83}$ This was a political as well as social comment, as the Essay tilted increasingly in its latter stages towards an overtly political sense of activity and a thinly disguised plea for a return to Charles II's government. A bitter reflection that witty men mock 'sobriety of advice' and make 'ridiculous' its giver (recalling the way in which Clarendon's enemy, the king's mistress Barbara Castlemaine, mimicked him) was coupled with an insistence that the virtuous are still obliged to give advice, however slandered, and an ever-optimistic sense that a monarch would eventually realise this was for their own good, though temporarily blinded by 'passion or appetite'. ${ }^{84}$ Like so many before him, Clarendon looked to counsel to solve the problems of monarchy. None knew better than he that advice often went unheeded, partly because of his opponents at court, partly because the two monarchs he served were flawed. Yet he was obliged to keep trying: obliged by charitable service to his fellow men and especially bound by the oath he had solemnly sworn. However problematic counsel proved, it could not be given up, for to abandon counsel would mean surrendering the fundamentals of monarchy.

${ }^{83}$ Edward Hyde, earl of Clarendon, An Essay on an Active and Contemplative Life (Glasgow, 1765), pp. 78, 91.

${ }^{84}$ Clarendon, Active Life, pp. 116-18. 